\title{
Water quality in the lotic area of the Antas River \\ before and after the construction of the Monte Claro hydroelectric plant, south Brazil
}

Qualidade da água nos trechos lóticos do Rio das Antas antes e após a construção da Usina Hidrelétrica Monte Claro, sul do Brasil

\author{
Adriane Marques Pimenta, Leonardo Marques Furlanetto, \\ Edélti Faria Albertoni and Cleber Palma-Silva \\ Programa de Pós-graduação em Biologia de Ambientes Aquáticos Continentais - PPG-BAC, \\ Universidade Federal do Rio Grande - FURG, Av. Itália, Km 08, s/n, Campus Carreiros, \\ CEP 96201-900, Rio Grande, RS, Brazil \\ e-mail: adrioceano@hotmail.com; lmfurlanetto@furg.br; dmbefa@furg.br; dmbcps@furg.br
}

\begin{abstract}
Aim: This study characterized the water quality of the lotic areas of the Rio das Antas (Antas River)influenced by the construction of the Monte Claro hydroelectric plant (South Brazil), a run-of-the-river reservoir. Methods: To assess the water quality, we selected four sampling points based on the results obtained in the water-quality monitoring program performed by CERAN (the Rio das Antas Energetic Company) in the pre-filling (2002-2004) and post-filling (2005-2008) periods. The river flow was monitored during both of the periods. Seasonal samplings were conducted, and alkalinity, chlorophyll $a$, total and fecal coliforms, conductivity, color, BOD, COD, total phosphorus, nitrate, nitrite, ammoniacal nitrogen, dissolved oxygen, $\mathrm{pH}$, total dissolved solids, suspended solids, sulfates, temperature and turbidity were evaluated. The results were interpreted according to the Brazilian Environmental Council's Water Quality Index, Trophic State Index and CONAMA Resolution 357/05. To verify the occurrence of alterations before and after the plant operation, $t$-tests were performed. Results: Significant changes in water quality were not observed after the impoundment. The permanence of the characteristics of the natural hydrography was important for maintaining the water quality. The decline of the water quality in a stretch with reduced flow was caused by Burati stream, a tributary containing high concentrations of nutrients and fecal coliforms. Conclusions: The Monte Claro hydroelectric plant did not alter the water quality of the Antas River. The small reservoir resulting from the plant project favors the maintenance of the water quality of the river and does not favor eutrophication. Attention should be given to Burati stream, a tributary of the Antas River, regarding its high nutrient and coliform content.
\end{abstract}

Keywords: Antas River, dams, stream limnology, WQI, TSI.

Resumo: Objetivos: Este estudo caracterizou a qualidade da água nos trechos lóticos do rio das Antas influenciados pela construção da usina hidrelétrica Monte Claro, com reservatório tipo fio d'água. Método: Foram selecionados quatro pontos do programa de monitoramento da qualidade da água executado pela CERAN - Companhia Energética rio das Antas, nos períodos pré-enchimento (2002-2004) e pós-enchimento (2005 a 2008). Foi monitorada a vazão do rio pré e pós-enchimento do reservatório. As amostragens foram sazonais, e utilizadas as variáveis alcalinidade, clorofila $a$, coliformes totais e fecais, condutividade, cor, DBO, DQO, fósforo total, nitrato, nitrito, nitrogênio amoniacal, oxigênio dissolvido, $\mathrm{pH}$, sólidos dissolvidos totais, sólidos suspensos, sulfatos, temperatura e turbidez. Estes resultados foram interpretados de acordo com a Resoluçáo CONAMA 357/05, o Índice de Qualidade da Água e Índice de Estado Trófico. Foi utilizado o teste-t para verificar a ocorrência de alteraçóes em um mesmo ponto antes e depois da entrada em operação da usina. Resultados: Não foram observadas mudanças significativas na qualidade da água depois do barramento. A permanência das características hidrográficas naturais foi importante na manutenção da qualidade da água. A diminuição da qualidade da água em trecho da alça de vazão reduzida foi provocada pela arroio Burati que desemboca no trecho e apresenta grande contribuição de nutrientes e coliformes fecais. Conclusóes: A usina hidroelétrica Monte Claro não alterou a qualidade de água do rio das Antas. O reservatório de dimensóes pequenas formado pelo projeto favorece a manutenção da qualidade de água do rio e não favorece a eutrofização. Deve ser dada atenção ao arroio Burati, tributário do rio das Antas, por sua alta concentração de nutrientes e de coliformes.

Palavras-chave: Rio das Antas, barragens, limnologia de rios, IQA, IET. 


\section{Introduction}

Long-term average river flows have been used internationally as good indicators of the renewable hydro potential that can be developed in terms of each state, watershed or geoeconomic planning unit. The construction of dams for various purposes is one of the oldest and most important human interventions in natural systems (Tundisi, 1999). The flow of approximately $60 \%$ of the world's rivers is regulated, and reservoirs cover a total area of $500,000 \mathrm{~km}^{2}$ (McAllister et al., 2001). Hydropower is considered by some authors to be renewable and an alternative to energy generation when compared to coal and oil, with lower emissions of gases that contribute to global warming (Mariuzzo, 2007).

The construction of large reservoirs in Brazil began in 1900 (Nogueira et al., 1999), and hydropower plants account for approximately $80 \%$ of the electricity supply in Brazil (Bermann et al., 2004). This pattern shows the strong dependence of the country on this type of energy source. Therefore, knowledge of the monthly average stream flow to assess the seasonal trends of water availability in a catchment area is a useful tool for water-resource management (Rebouças, 1997).

The Monte Claro hydroelectric plant, together with the Castro Alves and 14 de Julho plants, is a component of CERAN, the Rio das Antas Energetic Company (Companhia Energética Rio das Antas). The Monte Claro plant was the first of these three plants to be built. A pioneering installation, the Monte Claro hydroelectric power plant was listed under the criteria specified by the UNFCCC's Clean Development Mechanism, established in the Kyoto Protocol, for its contribution to reducing the emissions of greenhouse gases. In December 2007, through the Monte Claro Hydroelectric Power Plant, CERAN completed its first sale worldwide of Certified Emission Reductions (CERs) of $\mathrm{CO}_{2}$ coming from a run-of-the-river plant with more than $20 \mathrm{MW}$ (CERAN, 2012). One of the principal characteristics of the three plants is their operation as run-of-the-river (reservoir-river) hydro projects. In these systems, a portion of a river's water is diverted to a channel, pipeline, or pressurized pipeline (penstock) that delivers the water to a waterwheel or turbine (Machman-Hunt, 2001). The flow is fully allocated to the installed power-generation capacitor (Conceiçãa, 2007).

Plants with reservoir-river cascades experience great variations in the water flow of the river throughout the year and are forced to reduce their generation of electricity in the dry season
(ILUMINA, 2010). These small-dimension hydroelectric plants work by water trickle and have small reservoirs, which accumulate water according to the daily river-stream regime where they are situated (Tavares et al., 2004). The power plants consist of small reservoirs and a dam where most of the river water is deviated into a watering channel (river loop). The water is retained and is afterwards deviated through a derivation channel that runs parallel to the river into the hydroelectric central, where, after being turbinated, the water returns to the original stream.

The natural regime of a river is associated with different environmental variables, such as water temperature, sediment accumulation, nutrient concentrations, dissolved oxygen (Poff et al., 1997), and turbidity (Trepanier et al., 1996). Reservoirs that do not have to regulate the flow capacity do not change the natural river regime. The Monte Claro hydroelectric plant does not have to regulate the flow capacity and therefore forms small water reservoirs that do not alter the river natural flow to the same extent as a large hydroelectric plant.

Many indices of water quality are used internationally, and most of these indices were developed for temperate conditions. Modifications of these indices adapted to the characteristics of tropical and subtropical environments have been developed and are currently used for Brazilian waters. The use of these indices to classify Brazilian waters is supported by Brazilian environmental legislation. The water-quality index defined by the National Sanitation Foundation (USA) was adapted by Bendati et al. (2003), and the Trophic State Index (TSI) of Carlson (1977) was adapted by CETESB (2009) (Technology Company of Environmental Sanitation of the State of São Paulo, Brazil).

The purpose of this study is to characterize the water quality in the lotic areas influenced by the Monte Claro hydroelectric plant based on the results obtained in the Limnological and Water Quality Monitoring Program of CERAN according to the classes defined by CONAMA Resolution 357/05, the Water-Quality Index (WQI), and the TrophicState Index (TSI). Our hypothesis is that small reservoirs developed in association with hydropower plants do not cause substantial changes in water quality in the lotic areas that are influenced while the reservoirs are being filled.

\section{Material and Methods}

\subsection{Study area}

The Antas River is a long water course, with approximately $530 \mathrm{~km}$ of extension in the 
northeastern Rio Grande do Sul state, Brazil. The river runs in a valley with preserved and urban areas (FEPAM, 2009). One of its tributaries is Burati stream, which receives effluents from the city of Bento Gonçalves before reaching the Monte Claro power plant. The Monte Claro is a hydroelectric plant located in the Antas River near the cities of Nova Roma do Sul, Veranópolis and Bento Gonçalves. The plant has the capacity to produce $130 \mathrm{MW}$. The reservoir area is $1.4 \mathrm{~km}^{2}$ at its normal water level, but it can reach $2.5 \mathrm{~km}^{2}$ during flooding periods. The volume is $11.28 \times 10^{6} \mathrm{~m}^{3}$, and the maximum depth is $25 \mathrm{~m}$ (CERAN, 2012) (Figure 1).

\subsection{Methodology}

Four sampling sites were analyzed according to the interpretative analysis of the results obtained during the Limnological Monitoring and Water Quality Program of CERAN (Rio das Antas Energetic Company) (Table 1, Figure 1) before (2002-2004) and after (2005-2008) the construction of the hydroelectric center. The sampling sites were chosen according to their positions: 1 , upstream of the plant; 2, Burati stream (a tributary); 3, at the stream channel (downstream of the reservoir in a stretch of reduced flow); and 4, in the downstream
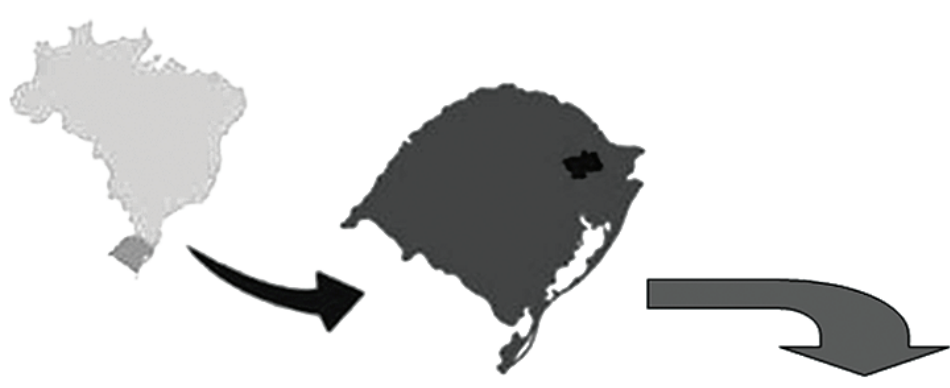

Adduction tunnel

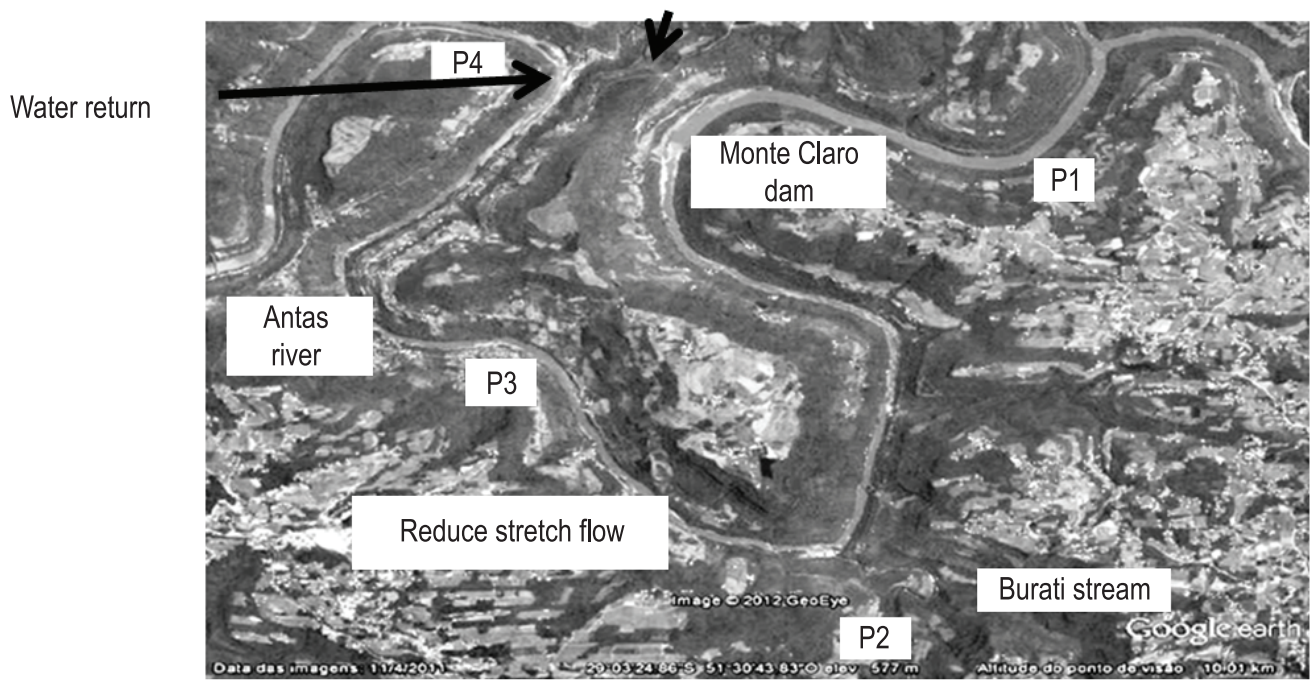

Figure 1. Map showing the location of the collection points. Source: Google Earth ${ }^{\odot}$.

Table 1. Location of the sampling sites.

\begin{tabular}{|c|c|c|}
\hline Sites & Location & Coordinates \\
\hline 1 & Antas river upstream from the Monte Claro reservoir. & $\begin{array}{r}29^{\circ} 02^{\prime} 49.98^{\prime \prime} \mathrm{S} \\
2^{\circ} 33^{\prime} 14.31^{\prime \prime} \mathrm{E}\end{array}$ \\
\hline 2 & Burati stream. & $\begin{array}{r}29^{\circ} 06^{\prime} 39.34^{\prime \prime} \mathrm{S} \\
2^{\circ} 30^{\prime} 00.75^{\prime \prime} \mathrm{E}\end{array}$ \\
\hline 3 & Antas river downstream the mouth of Burati stream. & $\begin{array}{r}29^{\circ} 03^{\prime} 42.79^{\prime \prime} \mathrm{S} \\
2^{\circ} 28^{\prime} 05.03^{\prime \prime} \mathrm{E}\end{array}$ \\
\hline 4 & Antas river downstream output of the Monte Claro power house. & $\begin{array}{r}29^{\circ} 01^{\prime} 03.26^{\prime \prime} \mathrm{S} \\
2^{\circ} 27^{\prime} 51.44^{\prime \prime} \mathrm{E}\end{array}$ \\
\hline
\end{tabular}


pipeline (where the diverted water returns to the stream channel).

The samplings were conducted seasonally, with a total of 28 samplings at each site. A sample of subsurface water from the side of the research vessel with a collector with a $1.5 \mathrm{~m}$ cable was collected. The alkalinity, chlorophyll $a$, fecal and total coliforms, conductivity, color, biochemical oxygen demand (BOD), chemical oxygen demand (COD), nitrates, ammoniacal nitrogen, dissolved oxygen, dissolved and suspended solids and sulfates were analyzed according to Standard Methods (APHA, 2005). The total phosphorus (TP), nitrite, $\mathrm{pH}$ and turbidity analyses followed the guidelines of the Brazilian Association of Technical Standards (ABNT), with the auditing standards NBR 12772/1992 (ABNT, 1992a), 12619/1992 (ABNT, 1992b), 14339/1999 (ABNT, 1999) and 11265/1990 (ABNT, 1990), respectively. To analyze the results, seasonal averages in the pre-filling (20022004) and post-filling (2005-2008) periods of the reservoir were calculated. To evaluate differences between these two periods (before and after filling the reservoir), the variables at each sample point were analyzed using a $t$-test for comparison for the average of the previous three years $(n=12)$ and the average of the four years after $(n=16)$ the plant's reservoir was filled.

The Brazilian Environment Council's CONAMA Resolution 357/05 (CONAMA, 2005), the Water-Quality Index (WQI) (Bendati et al., 2003) and the Trophic State Index (TSI) for rivers (CETESB, 2009) were used to interpret the results and evaluate the impact downstream. These indices are indicative of the water health for multiple users (Rosemond et al., 2009). According to Brazilian environmental council regulation, classes 1 and 2 indicate good water quality, whereas classes 3 and 4 indicate poor water quality.

The TSI and WQI ( $\mathrm{n}=12$ and $\mathrm{n}=16$ pre-and post-filling, respectively) were calculated at each sampling site. The following formula was used to calculate the WQI:

$\mathrm{WQI}=\Pi_{\mathrm{i}} \mathrm{w}_{\mathrm{i}}$

where: WQI - Water Quality Index, ranging from 0 to $100 ; \Pi-$ the sign symbol of the product operator; $\mathrm{q}_{\mathrm{i}}-$ the quality of the $\mathrm{i}_{\text {th }}$ variable; $\mathrm{a}$ number between 0 and 100, obtained from a graph of the variables, depending on the outcome of the analysis; $\mathrm{w}_{\mathrm{i}}$ - weight corresponding to the $\mathrm{i}_{\text {th }}$ variable set according to the importance of the variables in shaping the quality; a number between 0 and 1 , with the sum of all of the weights equal to 1 (ANA,
2005). The polynomial functions used to calculate the quality parameters for the 09 individual WQI were defined by Gastaldini and Mendonça (2003 apud Castro Júnior et al., 2007).

To calculate the TSI, the results for the total phosphorus and chlorophyll-a levels were used in the following equations:

TSI (CHL) $=10 \times(6-((-0,7-0,6 \times$

$(\ln \mathrm{CHL})) / \ln 2))-20$

TSI $(\mathrm{PT})=10 \times(6-((0,42-0,36 \times$ $(\ln \mathrm{PT})) / \ln 2))-20$

where: PT - The total phosphorus measured at the subsurface of the water in $\mu \mathrm{g} / \mathrm{L}$; CHL - Chlorophyll- $a$ concentrations measured in the subsurface water in $\mu \mathrm{g} / \mathrm{L}$; Ln - Natural logarithm.

The result of the TSI was the simple arithmetic average of the indices for the total phosphorus and chlorophyll, according to the following equation (CETESB, 2009):

$\mathrm{TSI}=[\mathrm{TSI}(\mathrm{PT})+\mathrm{TSI}(\mathrm{CHL})] / 2$

The limits for the different trophic classes of the river were ultraoligotrophic(TSI $\leq 47)$, oligotrophic $(47<$ TSI $\leq 52)$, mesotrophic $(52<$ TSI $\leq 59)$, eutrophic $(59<$ TSI $\leq 63)$, supereutrophic $(63<$ TSI $\leq 67)$ and hypereutrophic $($ TSI > 67).

The tributary flows (measured at the entrance of the reservoir) and treated flow (measured in the passage of reduced flow) were obtained directly from CERAN.

\section{Results}

\subsection{Flow}

The natural hydrographic characteristics of the Antas River were maintained after the formation of the reservoir (Figure 2). The peak flow rates before and after the reservoir formation remained similar in the stretch under the influence of the project and showed that the construction of the reservoir did not cause significant changes in the flow rate. The highest rates were recorded during spring in 2007 and 2008, both with values greater than $6400 \mathrm{~m}^{3} \cdot \mathrm{s}^{-1}$. During dry periods, the river flow was below $20 \mathrm{~m}^{3} . \mathrm{s}^{-1}$. The strongest period of drought was recorded during the summer of 2005, and a more prolonged drought occurred in the summer of 2006. This period lasted until the autumn of 2006.

\subsection{Water quality}

All of the sampling sites showed a higher frequency of quality classes 1 and 2 according to 

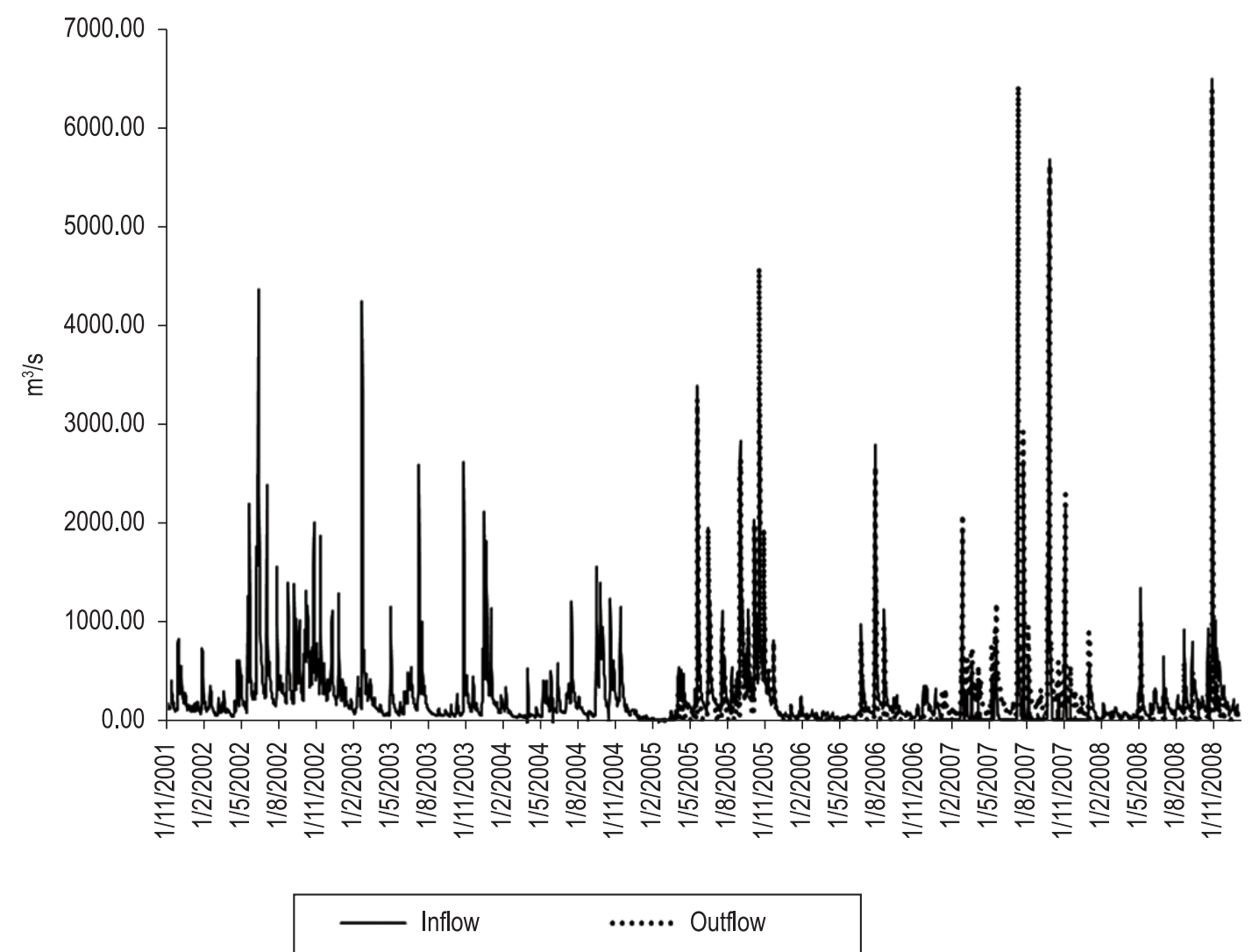

Figure 2. Variation of the influent flow upstream and into the stretch of reduced flow throughout the study period.

the CONAMA Regulation 357/05 (CONAMA, 2005) throughout the evaluated period (Table 2). Similarly, the TSI and WQI indices, both before and after the plant construction, showed the water quality to be poor or very poor on only a few occasions. This ranking was found only at $9 \%$ of the samplings before the reservoir formation, all at site 2 (Burati stream) (Table 2).

The variables alkalinity, total coliforms, conductivity, COD, suspended solids and silica are not addressed by CONAMA Resolution 357/05 (CONAMA, 2005). The variables ammoniacal nitrogen, dissolved oxygen, dissolved solids and sulfates presented results corresponding to classes 1 or 2 in all of the sampling sites.

Over $90 \%$ of the results obtained during the study corresponded to classes 1 or 2 . At site2, Burati stream, the occurrence of classes 1 or 2 reached a maximum of $86 \%$. At this site, classes 3 and 4 occurred with higher frequency, indicating higher degradation than at the other points. The parameters that exceeded class 2 at site 1 were BOD, TP and fecal coliforms in the period before the construction of the reservoir and BOD, TP, fecal coliforms, nitrate, nitrite, and chlorophyll $a$ after the impoundment (Table 3). At Burati stream (site 2), the color, turbidity, BOD, TP, nitrite and fecal coliform levels were higher than class 2 before the reservoir formation, and the color, $\mathrm{BOD}, \mathrm{TP}$, nitrate, nitrite and fecal coliform levels were higher than class 2 after the reservoir formation (Table 4). At site 3, the color, BOD, TP and fecal coliform levels were higher than class 2 before and after the impoundment, and at site 4, the BOD, TP and fecal coliform levels exhibited the same pattern (Table 5). At site 4 (where the river returns to its normal flow), the BOD, TP, and fecal coliform levels were higher than class 2 both before and after the impoundment.

According to the classification of the Trophic State Index (TSI), the sites were classified as predominantly ultraoligotrophic and mesotrophic. The frequency of super- and hypereutrophic states were lower in the pre-filling period than after the filling, but no significant differences were found between the two periods, showing that in general, there was no influence on the trophic state of the Antas River caused by the construction of the plant. Sites 1 (upstream reservoir) and 2 (Burati stream) presented supereutrophic and hypereutrophic characteristics at a higher frequency. At site 2, this result was mainly due to higher concentrations of TP, with means of $207.0 \mu \mathrm{g} . \mathrm{L}^{-1}$ before and 
Table 2. Frequency of occurrence of the CONAMA classes, TSI and WQI in the pre-(2002-2004) and post-filling (2005-2008) periods of the Monte Claro reservoir at the Antas River, Rio Grande do Sul, Brazil.

\begin{tabular}{|c|c|c|c|c|c|c|}
\hline Sites & $\begin{array}{l}\text { CONAMA } \\
\text { Classes }\end{array}$ & $\begin{array}{c}\text { TSI } \\
\text { Pre filling }\end{array}$ & WQI & $\begin{array}{c}\text { CONAMA } \\
\text { Classes }\end{array}$ & $\begin{array}{c}\text { TSI } \\
\text { Post filling } \\
\end{array}$ & WQI \\
\hline 1 & $\begin{array}{c}1-84 \% \\
2-10 \% \\
3-4 \% \\
4-2 \%\end{array}$ & $\begin{array}{l}\text { Ultra - } 70 \% \\
\text { Meso - } 10 \% \\
\text { Hyper - } 20 \%\end{array}$ & Good - $73 \%$ Accetable - $27 \%$ & $\begin{array}{c}1-78 \% \\
2-12 \% \\
3-6 \% \\
4-4 \%\end{array}$ & $\begin{array}{c}\text { Ultra - } 7 \% \\
\text { Oligo - } 13 \% \\
\text { Meso - } 40 \% \\
\text { Eut - } 20 \% \\
\text { Super - } 13 \% \\
\text { Hyper - } 7 \%\end{array}$ & $\begin{array}{c}\text { Good - } 60 \% \\
\text { Accetable }-40 \%\end{array}$ \\
\hline 2 & $\begin{array}{c}1-76 \% \\
2-10 \% \\
3-5 \% \\
4-9 \%\end{array}$ & $\begin{array}{c}\text { Ultra - } 55 \% \\
\text { Oligo - } 9 \% \\
\text { Eut - } 9 \% \\
\text { Super - 9\% } \\
\text { Hyper - 18\% }\end{array}$ & $\begin{array}{c}\text { Good - } 27 \% \text { Accetable - 55\% } \\
\text { Bad - 9\% Rubbish - 9\% }\end{array}$ & $\begin{array}{c}1-76 \% \\
2-10 \% \\
3-5 \% \\
4-9 \%\end{array}$ & $\begin{array}{c}\text { Ultra - } 14 \% \\
\text { Oligo - } 7 \% \\
\text { Meso - } 22 \% \\
\text { Eut - } 22 \% \\
\text { Super - } 21 \% \\
\text { Hyper } 14 \%\end{array}$ & $\begin{array}{c}\text { Accetable }-73 \% \\
\text { Bad }-27 \%\end{array}$ \\
\hline 3 & $\begin{array}{l}1-85 \% \\
2-11 \% \\
3-3 \% \\
4-1 \%\end{array}$ & $\begin{array}{c}\text { Ultra } 50 \% \\
\text { Oligo - } 17 \% \\
\text { Meso - } 25 \% \\
\text { Hyper - } 8 \%\end{array}$ & Good - 42\% Accetable - 58\% & $\begin{array}{c}1-83 \% \\
2-13 \% \\
3-2 \% \\
4-2 \%\end{array}$ & $\begin{array}{c}\text { Ultra - } 19 \% \\
\text { Oligo - } 19 \% \\
\text { Meso }-56 \% \\
\text { Eut - } 6 \%\end{array}$ & $\begin{array}{c}\text { Good }-50 \% \\
\text { Accetable - } 44 \% \\
\text { Bad - } 6 \%\end{array}$ \\
\hline 4 & $\begin{array}{c}1-84 \% \\
2-11 \% \\
3-4 \% \\
4-1 \%\end{array}$ & $\begin{array}{c}\text { Ultra - } 58 \% \\
\text { Oligo - } 8 \% \\
\text { Meso - } 25 \% \\
\text { Hyper - } 8 \%\end{array}$ & $\begin{array}{c}\text { Good }-42 \% \\
\text { Accetable }-58 \%\end{array}$ & $\begin{array}{c}1-81 \% \\
2-14 \% \\
3-3 \% \\
4-2 \%\end{array}$ & $\begin{array}{l}\text { Ultra - } 19 \% \\
\text { Oligo - } 13 \% \\
\text { Meso }-55 \% \\
\text { Eut - } 13 \%\end{array}$ & $\begin{array}{c}\text { Good }-50 \% \\
\text { Accetable - } 44 \% \\
\text { Bad }-6 \%\end{array}$ \\
\hline
\end{tabular}

$* 1,2,3$ and $4=$ CONAMA classes; Ultra $=$ ultraoligotrophic; Oligo $=$ oligotrophic; Meso $=$ mesotrophic; Eut $=$ eutrophic; Super $=$ supereutrophic; Hyper $=$ hypereutrophic .

Table 3. Maximum, minimum, mean and $\mathrm{p}$ values for each variable at site 1 .

\begin{tabular}{|c|c|c|c|}
\hline & Pre filling & Post filling & \\
\hline & Average (max-min) & Average (max-min) & $p$ \\
\hline Conductivity $\left(\mu \mathrm{mho} . \mathrm{cm}^{-1}\right)$ & $36.7(50.0-26.0)$ & $41.6(58.6-23.7)$ & 0.23 \\
\hline Color (mg. $\left.\mathrm{L}^{-1} \mathrm{CoPt}\right)$ & $28.6(70.0-5.0)$ & $32.7(60.0-5.0)$ & 0.41 \\
\hline Turbidity (NTU) & $14.5(29.1-3.7)$ & $16.3(96.2-3.6)$ & 0.99 \\
\hline $\mathrm{pH}$ & $6.8(7.2-6.3)$ & $7.1(7.4-6.1)$ & $0.03^{*}$ \\
\hline Alkalinity $\left(\mathrm{mg} \cdot \mathrm{L}^{-1} \mathrm{CaCO}_{3}\right)$ & $11.8(16.5-7.0)$ & $12.4(15.7-7.9)$ & 0.73 \\
\hline $\mathrm{BDO}\left(\mathrm{mg} \cdot \mathrm{L}^{-1} \mathrm{O}_{2}\right)$ & $3.9(7.0-0.6)$ & $3.5(8.3-2.0)$ & 0.69 \\
\hline $\mathrm{CDO}\left(\mathrm{mg} \cdot \mathrm{L}^{-1} \mathrm{O}_{2}\right)$ & $14.8(36.0-4.0)$ & $10.6(23.5-4.0)$ & 0.11 \\
\hline Total Phosphorus ( $\left.\mu \mathrm{g} \cdot \mathrm{L}^{-1} \mathrm{P}\right)$ & $59.9(120.0-11.9)$ & $98.1(242.0-26.7)$ & 0.09 \\
\hline Dissolved Oxygen $\left(\mathrm{mg}^{\mathrm{L}} \mathrm{L}^{-1} \mathrm{O}_{2}\right)$ & $8.5(11.4-7.1)$ & $8.6(10.9-7.3)$ & 0.53 \\
\hline Sulfates $\left(\mathrm{mg} \mathrm{L}^{-1} \mathrm{SO}_{4}^{-}\right)$ & $5.2(14.2-2.0)$ & $0.5(2.0-0.0)$ & $0.03^{*}$ \\
\hline Nitrates $\left(\mathrm{mg} \cdot \mathrm{L}^{-1} \mathrm{NO}_{3}^{-}\right)$ & $1.0(1.9-0.6)$ & $2.2(15.2-0.2)$ & 0.21 \\
\hline Nitrites (mg. $\mathrm{L}^{-1} \mathrm{NO}_{2}^{-}$) & $0.1(0.2-0.01)$ & $0.3(3.0-0.01)$ & 0.39 \\
\hline Ammoniacal Nitrogen $\left(\mathrm{mg} \cdot \mathrm{L}^{-1} \mathrm{~N}\right)$ & $0.3(0.85-0.05)$ & $0.2(0.55-0.00)$ & 0.31 \\
\hline Suspended Solids (mg. $\mathrm{L}^{-1}$ ) & $26.3(47.0-15.0)$ & $20.1(88.0-1.6)$ & 0.96 \\
\hline Dissolved Solids (mg. $\mathrm{L}^{-1}$ ) & $57.9(90.0-24.0)$ & $55.3(87.0-13.0)$ & 0.25 \\
\hline Chlorophyll-a ( $\left.\mu \mathrm{g} \cdot \mathrm{L}^{-1}\right)$ & $549.1(3,860-0.003)$ & $12.0(72.00-0.00)$ & $1.41 \mathrm{E}-20^{*}$ \\
\hline Total Coliforms (NMP.100 mL-1) & $13,500(110,000-23.00)$ & $105,647(800,175-0.04)$ & 0.18 \\
\hline Fecal Coliforms (NMP.100 mL-1) & $4,254.1(16,000-11.00)$ & $1,687.64(8,000-32.17)$ & 0.09 \\
\hline WQI & $70.4(83.6-52.2)$ & $72.7(88.1-64.3)$ & 0.51 \\
\hline TSI & $48.1(86.0-27.0)$ & $58.0(73.5-46.9)$ & 0.07 \\
\hline
\end{tabular}

*Significant difference $(\mathrm{p}<0.05)$ between pre-and post-filling.

$410.0 \mu \mathrm{g} . \mathrm{L}^{-1}$ after the reservoir construction; both of those values are higher than the maximum limit of $150 \mu \mathrm{g} . \mathrm{L}^{-1}$ recommended by the CONAMA regulation for class 2 . These concentrations were likely due to the input of urban sewage from the nearby cities. Chlorophyll-a presented lower average values after the plant construction $\left(2.90 \mu \mathrm{g} . \mathrm{L}^{-1}\right)$ that were lower than the $30 \mu \mathrm{g}$. $\mathrm{L}^{-1}$ limit for class 2 .

The Water-Quality Index (WQI) classified the water quality between good and acceptable at most 
Table 4. Maximum, minimum, mean and $\mathrm{p}$ values for each variable at site 2 .

\begin{tabular}{|c|c|c|c|}
\hline & Pre filling & Post filling & \\
\hline & Average (max-min) & Average (max-min) & $\mathrm{p}$ \\
\hline Conductivity $(\mu \mathrm{mho} / \mathrm{cm})$ & $83.4(150-31.2)$ & $136.9(322.0-59.8)$ & $0.04^{*}$ \\
\hline Color (mg. $\left.\mathrm{L}^{-1} \mathrm{CoPt}\right)$ & $33.8(100.0-10.0)$ & $32.1(100.0-5.0)$ & 0.88 \\
\hline Turbidity (NTU) & $20.7(102.8-3.0)$ & $14.4(82.9-2.2)$ & 0.50 \\
\hline $\mathrm{pH}$ & $7.0(7.4-6.5)$ & $7.2(7.5-6.0)$ & 0.30 \\
\hline Alkalinity $\left(\mathrm{mg} \cdot \mathrm{L}^{-1} \mathrm{CaCO}_{3}\right)$ & $19.9(30.5-14.0)$ & $21.4(50.2-9.6)$ & 0.68 \\
\hline $\mathrm{BDO}\left(\mathrm{mg} \cdot \mathrm{L}^{-1} \mathrm{O}_{2}\right)$ & $4.1(15.1-0.1)$ & $4.3(17.0-2.0)$ & 0.91 \\
\hline $\mathrm{CDO}\left(\mathrm{mg} \cdot \mathrm{L}^{-1} \mathrm{O}_{2}\right)$ & $15.1(32.0-4.0)$ & $11.0(23.7-4.0)$ & 0.23 \\
\hline Total Phosphorus $\left(\mu \mathrm{g} \cdot \mathrm{L}^{-1} \mathrm{P}\right)$ & $207.0(560.0-30.0)$ & $410.0(1,080.0-156.0)$ & 0.053 \\
\hline Dissolved Oxygen (mg. $\left.\mathrm{L}^{-1} \mathrm{O}_{2}\right)$ & $8.3(11.2-5.7)$ & $7.6(10.3-6.3)$ & 0.19 \\
\hline Sulfates $\left(\mathrm{mg} \cdot \mathrm{L}^{-1} \mathrm{SO}_{4}^{-}\right)$ & $5.6(14.3-1.2)$ & $6.4(16.7-1.6)$ & 0.96 \\
\hline Nitrates $\left(\mathrm{mg} \cdot \mathrm{L}^{-1} \mathrm{NO}_{3}^{-}\right)$ & $4.5(10.0-0.9)$ & $7.0(27.3-0.6)$ & 0.35 \\
\hline Nitrites $\left(\mathrm{mg} \cdot \mathrm{L}^{-1} \mathrm{NO}_{2}^{-}\right)$ & $0.3(1.7-0.01)$ & $0.4(1.84-0.01)$ & 0.86 \\
\hline Ammoniacal Nitrogen $\left(\mathrm{mg} \cdot \mathrm{L}^{-1} \mathrm{~N}\right)$ & $0.26(0.97-0.03)$ & $0.40(1.21-0.02)$ & $2.80 \mathrm{E}-05^{*}$ \\
\hline Suspended Solids $\left(\mathrm{mg} \cdot \mathrm{L}^{-1}\right)$ & $34.9(145.0-7.0)$ & $18.7(85.0-4.3)$ & 0.53 \\
\hline Dissolved Solids (mg. $\mathrm{L}^{-1}$ ) & $88.2(167.0-12.0)$ & $120.9(189.0-41.0)$ & $0.03^{*}$ \\
\hline Chlorophyll-a $\left(\mu \mathrm{g} \cdot \mathrm{L}^{-1}\right)$ & $460.6(2,500-0.01)$ & $2.90(8.30-0.01)$ & $0.03^{*}$ \\
\hline Total Coliforms (NMP.100 mL-1) & $164,830(1600,000-140.00)$ & $351,507.69(1072,333.33-800)$ & $0.02^{*}$ \\
\hline Fecal Coliforms (NMP.100 mL ${ }^{-1}$ ) & $164,206(1600,000-110.00)$ & $82,393.44(540,000-80.00)$ & 0.41 \\
\hline WQI & $58.5(75.3-25.4)$ & $54.8(66.6-33.0)$ & 0.15 \\
\hline TSI & $54.7(85.4-36.1)$ & $57.5(67.2-36.3)$ & 0.39 \\
\hline
\end{tabular}

*Significant difference $(\mathrm{p}<0.05)$ between pre-and post-filling.

Table 5. Maximum, minimum, mean and p values for each variable at site 3 .

\begin{tabular}{|c|c|c|c|}
\hline & Pre filling & Post filling & \\
\hline & Average (max-min) & Average (max-min) & $\rho$ \\
\hline Conductivity $(\mu \mathrm{mho} / \mathrm{cm})$ & $37.0(49.0-29.7)$ & $47.2(62.6-25.9)$ & $0.02^{*}$ \\
\hline Color (mg. L-1 CoPt) & $38.8(140.0-5.0)$ & $25.8(65.0-5.0)$ & 0.35 \\
\hline Turbidity (NTU) & $14.9(27.0-4.0)$ & $10.7(26.2-2.0)$ & 0.09 \\
\hline $\mathrm{pH}$ & $6.8(7.3-6.3)$ & $7.3(7.6-7.0)$ & $1.25 \mathrm{E}-3^{*}$ \\
\hline Alkalinity (mg. $\mathrm{L}^{-1} \mathrm{CaCO}_{3}$ ) & $14.3(22.5-10.0)$ & $17.4(28.7-10.7)$ & 0.22 \\
\hline $\mathrm{BDO}\left(\mathrm{mg} / \mathrm{L} \mathrm{O}_{2}\right)$ & $2.7(7.0-0.12)$ & $3.2(8.9-1.0)$ & 0.32 \\
\hline $\mathrm{CDO}\left(\mathrm{mg} / \mathrm{L} \mathrm{O}_{2}\right)$ & $15.6(44.0-4.0)$ & $11.0(21.6-6.0)$ & 0.13 \\
\hline Total Phosphorus ( $\left.\mu \mathrm{g} \cdot \mathrm{L}^{-1} \mathrm{P}\right)$ & $75.5(171.0-8.3)$ & $80.4(185.0-36.0)$ & 0.83 \\
\hline Dissolved Oxygen (mg. $\mathrm{L}^{-1} \mathrm{O}_{2}$ ) & $8.5(10.8-7.1)$ & $7.8(8.7-5.9)$ & 0.22 \\
\hline Sulfates $\left(\mathrm{mg} \cdot \mathrm{L}^{-1} \mathrm{SO}_{4}^{-}\right)$ & $4.8(8.1-2.8)$ & $1.5(8.4-0.0)$ & 0.66 \\
\hline Nitrates (mg. $\left.\mathrm{L}^{-1} \mathrm{NO}_{3}^{-}\right)$ & $1.1(1.6-0.7)$ & $1.0(2.7-0.2)$ & 0.69 \\
\hline Nitrites (mg. $\left.\mathrm{L}^{-1} \mathrm{NO}_{2}^{-}\right)$ & $0.04(0.13-0.01)$ & $0.02(0.05-0.01)$ & 0.13 \\
\hline Ammoniacal Nitrogen $\left(\mathrm{mg} \cdot \mathrm{L}^{-1} \mathrm{~N}\right)$ & $0.19(0.56-0.02)$ & $0.23(0.58-0.02)$ & 0.73 \\
\hline Suspended Solids (mg. $\mathrm{L}^{-1}$ ) & $19.9(32.0-8.0)$ & $10.9(27.5-6.0)$ & 0.42 \\
\hline Dissolved Solids (mg. $\mathrm{L}^{-1}$ ) & $61.4(117.0-17.0)$ & $68.5(91.0-40.7)$ & 0.80 \\
\hline Chlorophyll-a $\left(\mu \mathrm{g} \cdot \mathrm{L}^{-1}\right)$ & $111.4(1,110.00-0.01)$ & $2.7(10.67-0.08)$ & $8.41 \mathrm{E}-28^{*}$ \\
\hline Total Coliforms (NMP .100 $\mathrm{mL}^{-1}$ ) & $1,662.50(9,000.00-280.00)$ & $60,512.78(615,966.67-430.00)$ & 0.24 \\
\hline Fecal Coliforms (NMP .100 mL-1) & $495.75(2,200.00-40.00)$ & $616.93(3,300.00-23.00)$ & 0.39 \\
\hline WQI & $69.7(74.9-63.1)$ & $68.9(79.7-34.4)$ & 0.90 \\
\hline TSI & $47.8(82.2-34.1)$ & $51.6(59.9-30.9)$ & 0.27 \\
\hline
\end{tabular}

*Significant difference $(\mathrm{p}<0.05)$ between pre-and post-filling. 
of the collection sites and also showed no significant differences between the pre- and post-filling periods. During the period prior to the reservoir filling, only Burati stream (point 2) presented water of poor quality. In the period after the filling, this poor quality was reflected at the sites located downstream of this site (3 and 4).

The results of the monitored variables were compared in two blocks, representing the two periods before and after the construction of the reservoir. The average, maximum and minimum values for each variable are presented in Tables 3 to 6. At site 1, upstream of the plant reservoir, only the $\mathrm{pH}$, sulfates and chlorophyll-a presented significant differences: the $\mathrm{pH}$ had higher values after the filling (mean 7.1), and sulfates (5.2 to $0.5 \mathrm{mg} . \mathrm{L}^{-1}$ ) and chlorophyll-a (549.1 to $\left.11.06 \mu \mathrm{g} . \mathrm{L}^{-1}\right)$ had lower values. The variables with decreased mean values were BDO, CDO, ammoniacal nitrogen, suspended and dissolved solids and fecal coliforms (Table 3).

Site 2, located in the Burati stream, showed a greater number of variables with evidence of a change in water quality between the pre- and post-filling periods. The variables that showed increased values were $\mathrm{BDO}$, sulfates, nitrates, nitrites, ammoniacal nitrogen and total coliforms (Table 4). However, significant differences were detected regarding higher values for conductivity
(83.4 to $136.9 \mu \mathrm{mho} / \mathrm{cm}$ ), ammoniacal nitrogen (0.3 to $\left.0.40 \mathrm{mg} . \mathrm{L}^{-1}\right)$, total coliforms $(164,830.0$ to 351,507.7 NMP.100 $\mathrm{mL}^{-1}$ ), and dissolved solids (88.2 to $120.9 \mathrm{mg} . \mathrm{L}^{-1}$ ) as well as lower values for chlorophyll- $a$ (460.0 to $2.90 \mu \mathrm{g} . \mathrm{L}^{-1}$ ).

At site 3, located in the reduced-flow stretch, the conductivity $\left(37.0\right.$ to $47.2 \mu \mathrm{mho}^{\mathrm{cm}} \mathrm{cm}^{-1}$ ), $\mathrm{pH}$ (6.8 to 7.3 ), and chlorophyll-a (111.4 to $\left.2.7 \mu \mathrm{g} . \mathrm{L}^{-1}\right)$ were significantly different between the two periods (Table 5). Site 4, located in the area where water is returned to the river, showed $\mathrm{pH}$ (6.7 to 7.2 ), dissolved oxygen (8.4 to $7.4 \mathrm{mg} . \mathrm{L}^{-1}$ ), and chlorophyll-a (172.3 to $2.6 \mu \mathrm{g} . \mathrm{L}^{-1}$ ) levels with significant differences between the pre- and post-filling periods of the reservoir (Table 6). Most of the variables representing nutrient increments (TP, nitrate, nitrite, and sulfate) presented reduced values, and ammoniacal nitrogen had a slow incremental change $\left(0.2\right.$ to $\left.0.3 \mathrm{mg} . \mathrm{L}^{-1}\right)$, but the values were still within the limits of good water quality according to the CONAMA resolution.

\section{Discussion}

\subsection{Flow}

A comparison of the natural flow regime of a river with the flow regime that is affected

Table 6. Maximum, minimum, mean and $\mathrm{p}$ values for each variable at site 4 .

\begin{tabular}{|c|c|c|c|}
\hline & Pre filling & Post filling & \multirow{2}{*}{$\mathbf{p}$} \\
\hline & Average (max-min) & Average (max-min) & \\
\hline Conductivity $(\mu \mathrm{mho} / \mathrm{cm})$ & $37.5(49.0-32.0)$ & $44.0(63.1-25.4)$ & 0.10 \\
\hline Color (mg. $\left.\mathrm{L}^{-1} \mathrm{CoPt}\right)$ & $37.5(100.0-5.0)$ & $26.9(60.0-5.0)$ & 0.32 \\
\hline Turbidity (NTU) & $14.7(28.3-3.5)$ & $10.6(21.2-2.3)$ & 0.08 \\
\hline $\mathrm{pH}$ & $6.7(7.2-6.3)$ & $7.2(7.5-7.0)$ & $1.0 \mathrm{E}-3^{*}$ \\
\hline Alkalinity $\left(\mathrm{mg} \cdot \mathrm{L}^{-1} \mathrm{CaCO}_{3}\right)$ & $14.1(22.5-10.0)$ & $15.6(28.5-9.5)$ & 0.63 \\
\hline $\mathrm{BDO}\left(\mathrm{mg} \cdot \mathrm{L}^{-1} \mathrm{O}_{2}\right)$ & $3.1(6.0-0.5)$ & $3.2(8.4-1.7)$ & 0.78 \\
\hline $\mathrm{CDO}\left(\mathrm{mg} \cdot \mathrm{L}^{-1} \mathrm{O}_{2}\right)$ & $18.5(56.0-4.0)$ & $9.9(16.0-6.0)$ & 0.054 \\
\hline Total Phosphorus $\left(\mu \mathrm{g} \cdot \mathrm{L}^{-1} \mathrm{P}\right)$ & $83.3(175.9-17.2)$ & $80.2(238.0-27.0)$ & 0.69 \\
\hline Dissolved Oxygen (mg. $\mathrm{L}^{-1} \mathrm{O}_{2}$ ) & $8.4(10.8-7.2)$ & $7.4(8.7-5.8)$ & $0.05^{*}$ \\
\hline Sulfates $\left(\mathrm{mg} \cdot \mathrm{L}^{-1} \mathrm{SO}_{4}^{-}\right)$ & $4.9(8.1-2.0)$ & $1.6(8.5-0.0)$ & 0.052 \\
\hline Nitrates $\left(\mathrm{mg} \cdot \mathrm{L}^{-1} \mathrm{NO}_{3}^{-}\right)$ & $1.0(1.8-0.1)$ & $0.9(3.3-0.2)$ & 0.66 \\
\hline Nitrites $\left(\mathrm{mg} \cdot \mathrm{L}^{-1} \mathrm{NO}_{2}^{-}\right)$ & $0.04(0.14-0.01)$ & $0.02(0.07-0.01)$ & 0.08 \\
\hline Ammoniacal Nitrogen $\left(\mathrm{mg} \cdot \mathrm{L}^{-1} \mathrm{~N}\right)$ & $0.2(0.56-0.05)$ & $0.3(0.60-0.05)$ & 0.14 \\
\hline Suspended Solids $\left(\mathrm{mg} \cdot \mathrm{L}^{-1}\right)$ & $19.3(32.0-5.0)$ & $13.5(34.0-3.3)$ & 0.49 \\
\hline Dissolved Solids (mg. $\mathrm{L}^{-1}$ ) & $46.9(110.0-2.9)$ & $51.1(72.3-23.0)$ & 0.83 \\
\hline Chlorophyll-a ( $\left.\mu \mathrm{g} \cdot \mathrm{L}^{-1}\right)$ & $172.3(1,720.00-0.01)$ & $2.62(8.70-0.02)$ & 1.66E-31* \\
\hline Total Coliforms (NMP .100 mL-1) & $1,150.83(3,000.00-280.00)$ & $86,522.22(627,233.33-170.00)$ & 0.19 \\
\hline Fecal Coliforms (NMP .100 $\mathrm{mL}^{-1}$ ) & $409.00(1,300.00-8.00)$ & $997.09(4,900.00-10.67)$ & 0.17 \\
\hline WQI & $69.9(74.0-65.4)$ & $69.5(82.3-47.5)$ & 0.66 \\
\hline TSI & $44.0(85.78-27.92)$ & $50.3(59.2-27.9)$ & 0.31 \\
\hline
\end{tabular}

*Significant difference $(\mathrm{p}<0.05)$ between pre-and post-filling. 
by human intervention indicates the degree of human alteration or degradation of the freshwater ecosystem (Döll et al., 2009). Many studies have shown that flow regimes play a major role in determining the biotic composition, structure, function and diversity within river ecosystems (Poff and Ward, 1989; Poff et al., 1997).

The flow hydrography of the Antas River retained the same characteristics of the pulses observed in their natural course, even with the reduction of part of the flow for energy production. Large pulses of flow, characteristic of upland rivers, were kept downstream. The Monte Claro hydroelectric power plant maintained the natural hydrography of the river in the stretch downstream of the reservoir. Therefore, even without an analysis of the biotic communities, we can predict that their structure and function were maintained with only slight alterations.

\subsection{Water quality}

Several methods have been developed to evaluate the trophic state of aquatic environments (Sager and Lachavanne, 2009). Due to the difficulty of establishing well-defined boundaries between different trophic states using the concentration of the main nutrients in water, the most common approach used to define the trophic state of freshwater ecosystems is the total phosphorus level (Sager and Lachavanne, 2009).

Few of the variables showed a significant difference between the pre- and post-filling periods. Among the 20 variables studied, including the water quality and trophic state indices, only 11 showed differences in some of the sites monitored, as shown in Tables 2 to 5 . The site that had the greatest number of variables with significant differences was site 2, Burati stream (Table 3). The point with the fewest changes in parameters was site 4 , located at the point of the return of the water to the Antas River after power generation (Table 5).

According to Braccialli et al. (2007), the most important variables for the characterization of an aquatic system are the water temperature, dissolved oxygen, $\mathrm{pH}$, turbidity, dissolved solids and electrical conductivity. Tundisi (2000) stated that the destabilization of an aquatic system occurs when the physical, chemical and biological features, such as the total dissolved solids, $\mathrm{pH}$ and electrical conductivity, among others, are changed. The $\mathrm{pH}$ was the only variable that showed significant differences at all of the sites located in Antas River. The other variables showed significant difference at a maximum of two sites. The significant differences found in the outcome of these variables between the two different study periods may be indicative of the increased urbanization in the surrounding urban areas and not a result of the impoundment itself. The period covered in this study was the period before filling the reservoir and soon after the reservoir's formation.

The conductivity and dissolved solids differed between the Burati Stream (site 2) and site 3, immediately downstream. The Burati stream presents an environment that is severely degraded due to the influence of domestic sewage because this water course passes through Bento Gonçalves, with more than 100,000 citizens (FEE, 2011), and receives urban effluents. Higher levels of the monitoring variables were noticed more often at this site, with the values for total and fecal coliforms, conductivity and dissolved solids always showing an increase relative to other sites. Burati stream is a tributary of the Antas River, but it is not influenced by the reservoir. Therefore, the variables that could be responsible for diminishing the water quality of the Antas River are likely the result of the input of Burati stream once it flows into the Antas River and not the result of construction of the hydroelectric plant. This stream was the site with the greatest number of variables with significant differences between the pre- and post-filling periods, and we observed high values that were quite different from those of the other sites in the Antas River.

The indices used to interpret the results also showed no significant differences between the two periods. The water quality was considered good according to the methodology used, and most of the variables showed no change due to the reservoir formation, indicating that the water quality in this environment did not change. The results showed a low influence of the reservoir formation. The hydrogeological characteristics of the Antas River may be a factor that contributes to the maintenance of water quality because according Caputo et al. (2008), plateau rivers have turbulence, which ensures good aeration and a good depuration ability. In some rivers that do not have dams to generate hydroelectric electricity, results are often found indicating water quality worse than that of the Antas River, as reported by Alves et al. (2012) for the Arari River in the northern region of Brazil.

According to CONAMA Resolution 357/05 (CONAMA, 2005), water-quality classes 1 and 2 prevailed at all of the sampling sites and throughout the monitoring period. These classes indicate 
water that is safe, following simplified treatment, for human supply, the protection of aquatic communities, primary recreation, irrigation and aquaculture. The natural flow pulses, which have been maintained since construction of the reservoir, are important because they help maintain the water quality. Local use and land cover maybe a cause of major interference in the water quality in the Antas River, especially if we consider the water quality of Burati stream, which had the highest occurrences of classes 3 and 4 according to CONAMA Resolution 357/05. These classifications resulted from high levels of total phosphorus, fecal coliforms and BOD, indicating changes in water quality due to loading with domestic sewage.

In the Gravatai River, located near the TaquariAntas basin, Salomoni et al. (2007) observed changes in water quality due to discharge of domestic sewage in natura, as reflected in an increase of labile organic matter with high values of BOD, fecal coliforms, nutrients and turbidity. Morrice et al. (2008) found that the human population level is the strongest predictor of phosphorus levels and an important factor affecting water quality. Pollutants resulting from agricultural surface runoff are composed of sediments, nutrients, agrochemicals and animal waste (Merten and Minella, 2002).

The results obtained by calculating the trophicstate index (44 to 58) showed classifications predominantly between ultraoligotrophic and mesotrophic levels in the study site. These results may reflect the high flows that help carry and dilute nutrients as well as increase the difficulty encountered by phytoplankton attempting to settle in these places (where the velocity is higher). The total phosphorus and chlorophyll-a levels were used to calculate the index. High concentrations of total phosphorus were found at all of the sites (between 59.9 and $\left.410.0 \mu \mathrm{g} . \mathrm{L}^{-1}\right)$. Therefore, the values of the TSI, mainly in the post-filling period, seem to have a greater influence on the low values of chlorophyll-a.

In lotic environments, there has been little research conducted on water quality by relating the concentrations of nutrients and algal growth (based on chlorophyll-a) (Calijuri et al., 2008). Phosphorus is widely used in fertilizers and other chemicals, and high concentrations of phosphorus in streams can be associated with inadequate agricultural practices and urban-runoff discharges. In rivers, it is more difficult to perceive a correlation between the concentrations of chlorophyll- $a$ and nutrients. The response of chlorophyll $a$ to nutrient enrichment is likely constrained by physical factors, such as limited light, water turbulence and short hydraulic residence time (Calijuri et al., 2008).

The Burati stream was the most degraded site of the study area. All of the methods used in this study to evaluate the water quality reflect the characteristics of this stream in relation to other sites in the Antas River. The poor quality detected at this stream was not found in the sites located upstream of the outflow area of the Burati stream. The water quality in this stream was poor, according to the WQI, during $27 \%$ of the post-filling period . At points downstream, poor quality was observed during $6 \%$ of the monitored period. This reduction in the frequency of poor quality in the sites located downstream of this tributary reflects the efficient self-purification capacity of the Antas River. The peak flows in the downstream area are most likely crucial for dilution of the excess nutrients released by the Burati stream.

All of the methods used to assess the water quality proved to be suitable for the study area. The indices used (TSI and WQI) and Brazilian Environmental Council's CONAMA 357/05 showed that the regions of the Antas River in the area of influence of the Monte Claro hydroelectric plant maintained their water quality after the construction of the plant. However, the poor water quality of the tributary Burati stream, mainly driven by anthropogenic influence, must be addressed to avoid contamination of the Antas River.

\section{Acknowledgements}

We acknowledge the CERAN for data availability, CAPES for a scholarship to the first author, and the support of the Universidade Federal do Rio Grande (FURG).

\section{References}

ALVES, ICC., El-ROBRINI, M., SANTOS, MLS., MONTEIRO, SM., BARBOSA, LPF. and GUIMARÃES, JTF. 2012. Qualidade das águas superficiais e avaliação do estado trófico do Rio Arari (Ilha de Marajó, norte do Brasil). Acta Amazonica, vol. 42, no. 1, p. 115-124. http://dx.doi.org/10.1590/ S0044-59672012000100014

Agência Nacional das Águas - ANA. Hidroweb. 2005. Available from: <http://hidroweb.ana.gov.br/ HidroWeb/>. Access in: 14 dez. 2009.

American Public Health Association - APHA. 2005. Standard Methods for the Examination of Water and Wastewater. 20st ed. Washington: APHA.

Associação Brasileira de Normas Técnicas - ABNT. 1990. Águas minerais e de mesa - Determinação de turbidez - Método de ensaio. Rio de Janeiro: ABNT. 3 
p. Avaliablefrom: <www.abnt.org.br>. Access in: 14 dez. 2009.

Associação Brasileira de Normas Técnicas-ABNT. 1992a. Água - Determinação de fósforo. Rio de Janeiro: ABNT. 9 p. Avaliable from: <www.abnt.org.br>. Access in: 14 dez. 2009.

Associação Brasileira de Normas Técnicas - ABNT. 1992b. Água - Determinação de nitrito. Rio de Janeiro: ABNT. 4 p. Avaliable from: <www.abnt.org.br>. Access in: 14 dez. 2009.

Associação Brasileira de Normas Técnicas - ABNT. 1999. Água - Determinação de pH. Rio de Janeiro: ABNT. 3 p. Avaliable from: <www.abnt.org.br>. Access in: 14 dez. 2009.

BENDATI, MM., SCHWARZBACH, MSR., MAIZONAVE, CRM., ALMEIDA, LB. and BRINGHENTI, ML. 2003. Avaliação da qualidade da água do Lago Guaíba - Subsídios para a gestão da bacia hidrográfica. Ecos, vol. 4, no. 7.

BERMANN, C., VEIGA, JRC. and ROCHA, GS. 2004. A repotenciação de usinas hidrelétricas como alternativa para o aumento da oferta de energia no Brasil com proteção ambiental. WWF. Avaliable from: <www.projetobr.com.br/c/document_library/ get_file?folderId $=48>$.

BRACCIALLI, VL., HONDA, EA., NIZOLI, EC. and GÊNOVA, KB. 2007.Caracterização físico-química da água em reservatório situado em bacia hidrográfica florestada. Instituto Florestal Série Registros, vol. 31, p. 247-251.

CALIJURI, MC., CUNHA, DGF., QUEIROZ, LA., MOCCELLIN, J. and MIWA, ACP. 2008. Nutrients and chlorophyll- $a$ concentrations in tropical rivers of Ribeira de Iguape Basin, SP, Brazil. Acta Limnologica Brasiliensia, vol. 20, p. 131-138.

CAPUTO, L., NASELLI-FLORES, L., ORDONEZ, J. and ARMENGOL, J. 2008. Phytoplankton distribution along trophic gradients within and among reservoirs in Catalonia (Spain). Freshwater Biology, vol. 53, p. 2543-2556. http://dx.doi. org/10.1111/j.1365-2427.2008.02082.x

CARLSON, RE. 1977. A trophic state index for lakes. Limmology and Oceanography, vol. 22, p. 361-80. http://dx.doi.org/10.4319/lo.1977.22.2.0361

CASTRO JÚNIOR, RM., SOBREIRA, FG. and BORTOLOTI, FG. 2007. Modelagem Geoestatística a Partir de Parâmetros de Qualidade da Água (IQANSF) para a Sub-Bacia Hidrográfica do Rio Castelo (Es) Usando Sistema de Informaçóes Geográficas. Revista Brasileira de Cartografia, vol. 59, no. 03.

Companhia Energética Rio das Antas - CERAN. 2012. Compromisso com a sustentabilidade. Avaliable from: <www.ceran.com.br/session/viewPage/sectionId/3/ language/en_US/>. Access in: 14 jul. 2012.

Companhia Ambiental do Estado de São Paulo-CETESB. Secretaria de Estado do Meio Ambiente. 2009.
Avaliable from: <www.cetesb.sp.gov.br/Agua/rios/ indice_iva_iet.asp>. Access in: 08 dez. 2009.

Conselho Nacional de M e i o Ambiente - CONAMA. 2005. Resolução no 357, de 17 de março de 2005. Dispóe sobre a classificação dos corpos de água e diretrizes ambientais para o seu enquadramento, bem como estabelece as condiçóes e padrões de lançamento de efluentes, e dá outras providências. Diário Oficial da República Federativa do Brasil, Brasília, DF, 18 mar. 2005. Avaliable from: <http://www.mma.gov.br/port/conama/res/res05/ res35705.pdf $>$. Access in: 14 dez. 2009.

CONCEIÇÃO, AL. 2007. Análise sócio-econômica e cultural das pequenas centrais hidrelétricas do estado de São Paulo. Holos Environment, vol. 7, no. 1.

DÖLL, P., FIEDLER, K., and ZHANG, J. 2009.Globalscale analysis of river flow alterations due to water with drawals and Reservoirs. Hydrology and Earth System Sciences Discussions, vol. 6, p. 4773-4812. http://dx.doi.org/10.5194/hessd-6-4773-2009

Fundação de Economia e Estatística - FEE. 2011. População. Avaliable from: <http://www.fee.tche.br/ sitefee/pt/content/estatisticas/pg_populacao.php $>$. Access in: 06 ago. 2012.

Fundação Estadual de Proteção Ambiental - FEPAM. 2009. Qualidade Ambiental - Região Hidrográfica do Guaíba. Avaliable from: <www.fepam.rs.gov.br/qualidade/ qualidade_taquari_antas/taquariantas.asp $>$. Access in: $07 \mathrm{dez} .2009$.

Instituto do Desenvolvimento Estratégico do Setor Energético - ILUMINA. 2010. Avaliable from: <www.ilumina.org.br/zpublisher/secoes/home.asp>. Access in: 17 mar. 2010.

MACHMAN-HUNT, N. 2001. Small Hydropower Systems: Energy Efficiency and Renewable Energy Clearinghouse (EREC) Fact Sheet. U.S. Department of Energy, National Renewable Energy Laboratory. 8 p. Report FS217.

McALLISTER, DE., CRAIG, JF., DAVIDSON, N., DELANY, S. and SEDDON, M. 2001. Biodiversity Impacts of Large Dams. Gland: International Union for Conservation of Nature, and United Nations Environmental Programme, Switzerland. (IUCN/ UNEP/WCD, Background Paper, no. 1).

MARIUZZO, P. 2007. Hidrelétricas são a opção energética mais limpa e barata para o Brasil. Inovação Uniemp, vol. 3, p. 6-9.

MERTEN, GH. and MINELLA, JP. 2002.Qualidade da água em bacias hidrográficas rurais: um desafio atual para a sobrevivência futura. Agroecologia $e$ Desenvolvimento Rural Sustentável, vol. 3, no. 4.

MORRICE, JA., DANZ, NP., REGAL, RR., KELLY, JR., NIEMI, GJ., REAVIE, ED., HOLLENHORST, T., AXLER, RP., TREBITZ, AS., COTTER, AM. and PETERSON, GS. 2008. Human influences 
on water quality in Great Lakes coastal wetlands. Environmental Management, vol. 41, p. 347-357. PMid:18097715. http://dx.doi.org/10.1007/ s00267-007-9055-5

NOGUEIRA, MG., HENRY, R. and MARICATTO, FE. 1999. Spatial and temporal heterogeneity in the Jurumirim Reservoir, São Paulo, Brazil. Lakes Reservoir Research and Management, vol. 4, p. 107-20. http://dx.doi.org/10.1046/j.14401770.1999.00086.x

POFF, NL., ALLAN, JD., BAIN, MB., KARR, JR., PRESTEGAARD, KL., RICHTER, BD., SPARKS, RE. and STROMBERG, JC. 1997. The natural flow regime: a paradigm for river conservation and restoration. BioScience, vol. 47, p. 769-784.

POFF, NL. and WARD, JV. 1989.Implications of stream flow variability and predictability for lotic community structure: a regional analysis of stream flow patterns. Canadian Journal of Fisheries and Aquatic Science, vol. 46, p. 1805-1818. http://dx.doi. org/10.1139/f89-228

REBOUÇAS, AC. 1997. Água da região nordeste: desperdício e escassez. Estudos Avançados, vol. 11, no. 29.

ROSEMOND, S., DURO, DC. and DUBÉ, M. 2009. Comparative analysis of regional water quality in Canada using the Water Quality Index. Environment Monitoring Assessment, vol. 156, p. 223-240. http:// dx.doi.org/10.1007/s10661-008-0480-6
SAGER, L. and LACHAVANNE, JP. 2009. The M-NIP: a macrophyte-based Nutrient Index for Ponds. Hydrobiologia, vol. 634, p. 43-63. http://dx.doi. org/10.1007/s10750-009-9899-1

SALOMONI, SE., ROCHA, O. and LEITE, EH. 2007. Limnological characterization of Gravataí River, Rio Grande do Sul. Acta Limnologica Brasiliensia, vol. 19, p. 1-14.

TAVARES, GR., FORMIGO, N. and JESUS, T. 2004. Study of the impact of the discharges of the VilaViçosa small hydroelectric development (Portugal) on the water quality and on the fish communities of the Ardena river. Limnetica, vol. 23, no. 3-4, p. 271-282.

TREPANIER, S., RODRIGUEZ, MA. and MAGNAN, P. 1996. Spawning migrations in landlocked Atlantic salmon: time series modelling of river discharge and water temperature effects. Journal of Fish Biology, vol. 48, no. 5, p. 925-936. http://dx.doi. org/10.1111/j.1095-8649.1996.tb01487.x

TUNDISI, JG. 1999. Reservatórios como Sistemas Complexos: Teoria, Aplicaçóes e Perspectivas para Usos Múltiplos. In: HENRY, R., ed. Ecologia de Reservatórios: Estrutura, Função e Aspectos Sociais. Botucatu: FUNDIBIO; FAPESP. p. 19-38.

TUNDISI, JG. 2000. Limnologia e Gerenciamento Integrado de Recursos Hídricos: Avanços Conceituais e Metodológicos. Ciência \& Ambiente, vol. 1, p. 10-20. 